\title{
Harvest Strategies for an Ecosystem Approach to Fisheries Management in Western Mediterranean Demersal Fisheries
}

\section{OPEN ACCESS}

Edited by:

Christos Maravelias, Hellenic Centre for Marine Research,

Greece

Reviewed by:

Sanja Matic-Skoko,

Institute of Oceanography and

Fisheries, Croatia

Brett W. Molony,

Department of Fisheries, Western

Australia

*Correspondence:

Antoni Quetglas

toni.quetglas@ba.ieo.es

Specialty section:

This article was submitted to Marine Fisheries, Aquaculture and

Living Resources,

a section of the journal Frontiers in Marine Science

Received: 22 September 2016 Accepted: 30 March 2017

Published: 20 April 2017

Citation:

Quetglas A, Merino G, González J, Ordines F, Garau A, Grau AM, Guijarro $B$, Oliver $P$ and Massutí $E$ (2017) Harvest Strategies for an Ecosystem Approach to Fisheries

Management in Western Mediterranean Demersal Fisheries.

Front. Mar. Sci. 4:106.

doi: 10.3389/fmars.2017.00106

\begin{abstract}
Antoni Quetglas ${ }^{\text {* }}$, Gorka Merino ${ }^{2,3}$, Javier González ${ }^{1}$, Francesc Ordines ${ }^{1}$, Antoni Garau ${ }^{4}$, Antoni M. Grau ${ }^{5}$, Beatriz Guijarro ${ }^{1}$, Pere Oliver ${ }^{1}$ and Enric Massuti ${ }^{1}$

${ }^{1}$ Instituto Español de Oceanografía, Centre Oceanogràfic de les Balears, Palma de Mallorca, Spain, ${ }^{2}$ AZTI-Tecnalia, Herrera Kaia, Pasaia, Spain, ${ }^{3}$ Plymouth Marine Laboratory, Plymouth, UK, ${ }^{4}$ Federació Balear de Confraries de Pescadors, Palma de Mallorca, Spain, ${ }^{5}$ Direcció General de Pesca, Govern de les Illes Balears, Palma de Mallorca, Spain
\end{abstract}

The serious overfishing of most Mediterranean stocks demands urgent reforms of the management measures aiming to guarantee the sustainability of resources, notably when compared with the improvement observed in other European areas. The new EU Common Fisheries Policy (CFP) constitutes an excellent opportunity to introduce the changes needed for such a reform. According to this CFP, all European fish stocks should be brought to a state where they can produce at MSY by 2020 at the latest. The CFP also establishes that the objective of sustainable exploitation should be achieved through multiannual plans (MAPs) adopted in consultation with relevant stakeholders having fisheries management interests such as fishermen, non-governmental organizations, and policy makers. Together with the MSY and MAP approaches, the new CFP contains several other measures, directed to guarantee the ecological and socio-economic sustainability of fisheries by means of the implementation of the ecosystem approach to fisheries management (EAFM). With this new perspective, the CFP wants to avoid past failures of fisheries management based on monospecific approaches. This study is a first step toward the application of the EAFM in the Balearic Islands by means of the development of a harvest strategy with defined objectives, targets, limits, and clear management control rules aimed at optimizing socioeconomic and ecological objectives in the framework of the new CFP. Different management scenarios designed to achieve that goal were modeled for the main demersal commercial fisheries from the study area, the bottom trawl, and small-scale fisheries. The work begins with a general description of those fisheries, their main fishing grounds, and assessments of the exploitation status of the main target stocks in order to establish the current situation. Secondly, alternative management scenarios to maximize catch and profits while considering societal objectives were evaluated by means of bio-economic models. Thirdly, management measures were provided based on the previous modeling and discussions with stakeholders. Finally, a monitoring scheme was outlined to assess the progresses of the proposed management actions. This work is intended to be a working example of co-management (fishers, policy-makers, and scientists) in the Mediterranean in the framework of the new EU CFP.

Keywords: fisheries management, stakeholders, bottom trawl fishery, small-scale fishery, stock status, bioeconomic analysis 


\section{INTRODUCTION}

As stated in the Regulation No. 1380/2013 on the Common Fisheries Policy (CFP), the European Union (EU) should ensure that the exploitation of marine resources restores and maintains stocks above levels that can produce the maximum sustainable yield (MSY) by 2015 whenever possible or by 2020 at the latest. In fisheries, MSY is defined as the maximum catch that can be removed from a population over an indefinite period (Maunder, 2008). The MSY target proves specially challenging in mixed Mediterranean fisheries, where more than a hundred commercial species are landed (Lleonart and Maynou, 2003). As each species has specific MSYs, it is extremely difficult to regulate the fishing mortality for each of them independently (Ratz et al., 2007; Mackinson et al., 2009; Guillen et al., 2013), notably when the dynamics of these species may, in turn, be influenced by the environmental (i.e., climate) and fishing impacts (Mueter and Megrey, 2006). Achieving the MSY goal, therefore, is not an easy task because many different contrasting socioeconomic and ecological interests need to be confronted. At the practical level, the main constraints arise when maximizing yields demands socially unacceptable management measures implying drastic reductions of fishing exploitation rates. In order to minimize the negative effect of these measures while balancing the contrasting interests at play, it is essential to work with the active participation of the different actors involved in fisheries assessment and management (scientists, fishermen, and policymakers).

The EU Regulation also sets out that the objective of sustainable exploitation of marine biological resources is more effectively achieved through a multiannual approach to fisheries management, establishing as a priority multiannual plans (MAPs) reflecting the specificities of different fisheries. The MAPs should be based on scientific, technical, and economic advice and contain conservation measures to restore and maintain fish stocks above the MSY. Wherever possible, the MAPs should cover multiple stocks where those are jointly exploited. The MAPs should also establish the framework for the sustainable exploitation of stocks and marine ecosystems concerned, defining clear time-frames, and safeguard mechanisms for unforeseen developments. The Regulation also states that the MAPs should be adopted in consultation with Advisory Councils, operators in the fishing industry, scientists, and other stakeholders having an interest in fisheries management.

Together with the MSY and MAP approaches, the new CFP contains several other measures (e.g., fish recovery areas, landing obligation, and regionalization), directed to guarantee the ecological and socio-economic sustainability of fisheries. According to all these tenets, the new CFP is moving, in line with the current worldwide global trend (García et al., 2003; Pikitch et al., 2004; Link, 2013), toward the ecosystem approach to fisheries management (EAFM). With this new perspective, the CFP wants to avoid past failures of fisheries management based on monospecific assessment models (Jennings and Rice, 2011; Kvamsdal et al., 2016). Contrary to these models, the EAFM focuses on the need to make trade-offs among environmental, social, and economic objectives explicit to all stakeholders and to better inform decision-making (Jennings and Rice, 2011). Within the current framework of the EAFM, harvest strategies and harvest control rules (HCRs) have become an important tool, increasingly adopted to deal with uncertainty and ecosystem considerations, and to relieve management decisions from short-term political pressure (Kvamsdal et al., 2016). A harvest strategy should specify a process for monitoring and conducting assessments of the biological and economic conditions of the fishery as well as HCRs that control the intensity of fishing activity according to those fishery conditions (Dowling et al., 2008). The introduction of HCRs into modern fisheries management has led to a more complex framework and difficult policy choices, but has substantial benefits such as forcing political decisions to forsake short-term gains for longterm objectives (Deroba and Bence, 2008; Punt, 2010; Kvamsdal et al., 2016). There are different definitions, and even many types and configurations, of HCRs (for reviews, see Deroba and Bence, 2008; Punt, 2010; Kvamsdal et al., 2016). In short, HCRs are explicit guidelines to prevent future stock collapses and allow rebuilding of stocks that are already depleted (Kvamsdal et al., 2016). The success of HCRs is generally enhanced by involvement of stakeholders in the definition of the problem, including assumptions, and co-management (Dichmont et al., 2010). HCRs vary as a result of differences in governance needs and frameworks, but also the unique attributes, histories, and management requirements of each fishery (Kvamsdal et al., 2016). In consequence, the development of harvest strategies with HCRs is strongly related to the main tenets of the new EU CFP such as MAPs, regionalization and MSY target.

The Myfish project (myfishproject.eu/), financed by the EU Seventh Framework Programme, was aimed at analyzing the MSY target and MAP approach contemplated within the new CFP and thus to the delineation of harvest strategies including HCRs. The end result of the project was to construct an operational framework for the implementation of the MSY target as a tool for the future management of European fish stocks. The social dimension formed an integral part of the project whereby the cooperation with relevant stakeholders took place throughout its development to ensure that the management measures proposed were socially acceptable and desirable. The project analyzed five different regional case studies distributed from the Baltic in the north to the Mediterranean in the south. The Mediterranean case study was further split into two different areas, the Balearic Islands and the Aegean Sea in the western and eastern basin, respectively.

The Balearic Islands are one of the most distant insular areas in the Mediterranean, being separated from the Iberian Peninsula by depths of 2,000 m except in the Ibiza Channel (the nearest point between both coastlines) where the maximum depths are $800 \mathrm{~m}$. A comprehensive comparison including different aspects such as geomorphology, habitats, fisheries, and exploitation state of resources and ecosystems between the Balearic Islands and the adjacent coast of the Iberian Peninsula, concluded that the Archipelago should be maintained as an independent unit for assessment and management purposes in the western Mediterranean (Quetglas et al., 2012). 
In this paper, we present the regional implementation plan (RIP) for demersal fisheries of the Balearic Islands constructed in the framework of the Myfish project in close collaboration with the most relevant local stakeholders. By definition, the implementation plan constitutes a harvest strategy, including HCRs, aimed at achieving sustainable fisheries in line with Regulation 1380/2013 while balancing contrasting interests (ecosystem, economic, and social). Firstly, the work describes the main fisheries affected by the plan and provides stock assessments to know the exploitation status of the main target species in order to set up the current scenario in the study area. Secondly, alternative management scenarios directed toward maximizing catch and profits while considering societal objectives were evaluated by means of bio-economic models. Thirdly, a set of socially acceptable management measures were provided based on the previous modeling and a constant feed-back with stakeholders. Finally, a monitoring scheme is outlined to assess the progresses of the proposed management actions. The study is intended to be used as a first step toward the definition of MAPs in European fisheries in the study area and a working example of the CFP implementation in the Mediterranean.

\section{METHODS AND RESULTS}

The RIP for the Balearic Islands (western Mediterranean) was developed during the 4 years of the Myfish project (20122015) in tight collaboration between the scientists working in the project and the main local stakeholders involved in fisheries management: (i) the Fishermen Association; and (ii) the General Directorate of Fisheries of the Government. The collaboration of these two stakeholders included many meetings at local scale, attending different international meetings hold within the project, provision of fisheries data, facilitating cooperation, and feed-back with fishermen and participation in producing all relevant reports, scientific papers, and related material (e.g., DST, see below). The non-governmental organization (NGO) Oceana (oceana.org) published a report entitled Proposal for a responsible fishing in the Balearic Islands (Carreras and Cornax, 2011) in the form of five different leaflets including: (i) a global view of the local fisheries; (ii) recreational fisheries; (iii) small-scale fisheries; (iv) marine protected areas; and (v) bottom trawl fisheries. This material has also been analyzed and some proposals included in the RIP, which is therefore underpinned by the four main pillars of fisheries management (Aanesen et al., 2014; Röckmann et al., 2015): scientists, fishermen, policy-makers, and NGOs.

The RIP summarizes the main results of the Myfish project from the Balearic Islands case study. Being the main project aim to provide an operational framework for the implementation of the MSY concept in European waters, the following steps were undertaken to produce the RIP: (i) characterization of the relevant fisheries (fishing tactics, landings, CPUEs); (ii) description of the main fishing grounds; (iii) assessment of the stock status of the target species; (iv) bioeconomic analysis of the main fisheries to maximize economic yields and societal objectives; (v) produce Decision Support Tables (DSTs) as guidelines for managers; (vi) fish price analysis to improve the fisheries profitability; (vii) delineate management proposals to achieve the MSY target; and (viii) establish a monitoring scheme to assess the progresses of the RIP. A brief, general description of the analyses and methodologies used, together with the main results obtained, in all these steps are given below (for further details, see Myfish-RIP-WestMed-EN.pdf). Altogether, this RIP constitutes a harvest strategy for multispecies demersal fisheries from the western Mediterranean with defined objectives, targets, limits (thresholds), and clear management control rules aimed at optimizing socioeconomic and ecological objectives in the framework of Regulation No. 1380/2013.

The present RIP is focused on the main demersal commercial fisheries from the Balearic Islands, the bottom trawl (BTF) and small-scale (SSF) fisheries. The BTF landings account for $59 \%$ in terms of biomass and $64 \%$ in terms of incomes, while those of the SSF account for $20 \%$ in biomass and $27 \%$ in incomes. Owing to the importance of recreational fisheries in such an important tourist destination and its interactions with the professional fisheries, general information from available studies on this fishing practice, together with management measures, were also included.

Although the Balearic Islands are constituted by four main islands (Mallorca, Menorca, Ibiza, and Formentera), most of the analyses presented here were done using exclusively data from Mallorca because: (i) the reliability and availability of its fishery statistics is much better than those from the remaining islands; and (ii) its landings represent about $75 \%$ of the total Balearics landings.

\section{Fisheries Description}

The first step was the characterization of the main fisheries using different time series of fishery statistics provided by the fishermen association, such as landings, CPUEs, and number of vessels. Whereas, data from the BTF was available from previous studies (e.g., Ordines et al., 2006; Palmer et al., 2009; Quetglas et al., 2013), fishing tactics (a combination of target species, gear, and fishing location at a given time of the year; Pelletier and Ferraris, 2000), and fishery statistics from the SSF were determined within Myfish (for methodology, see Quetglas et al., 2016).

In the study area, commercial trawlers use up to four different fishing tactics (Palmer et al., 2009), which are associated with the shallow and deep continental shelf, and the upper and middle continental slope (Guijarro and Massuti, 2006; Ordines et al., 2006). Vessels mainly target striped red mullet (Mullus surmuletus) and European hake (Merluccius merluccius) on the shallow and deep shelf respectively. However, these two target species are caught along with a large variety of fish and cephalopod species. The Norway lobster (Nephrops norvegicus) and the red shrimp (Aristeus antennatus) are the main target species on the upper and middle slope respectively. The Norway lobster is caught at the same time as a large number of other fish and crustacean species, but the red shrimp fishery is the only Mediterranean BTF that could be considered monospecific. From 1965, the BTF from Mallorca has showed large variations in the number of vessels, mean engine power and the fishing time at sea (Figure 1). The number of trawlers doubled during the first 12 years and reached its maximum of 70 units in 1977, 


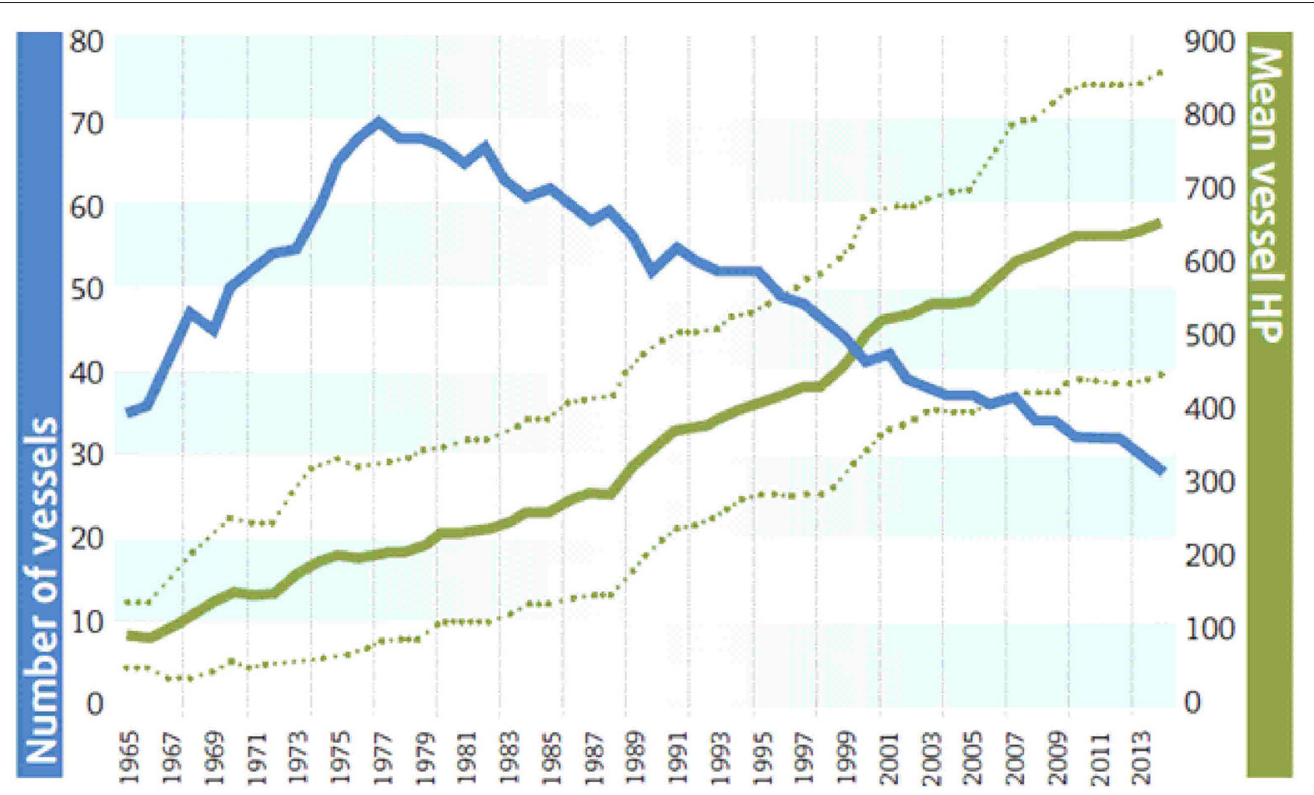

FIGURE 1 | Number of vessels along with its mean and standard deviation of gear power (HP) of the bottom trawl fleet from Mallorca (Balearic Islands) during 1965-2014.

but this number has decreased progressively since then and is currently (2014) lower than the initial number of vessels in 1965 (28 vs. 35$)$.

The SSF targets the following eight fishing tactics and corresponding target species: (i) purse seine: dolphinfish (Coryphaena hippurus); (ii) purse seine: transparent goby (Aphia minuta); (iii) handline: squid (Loligo vulgaris); (iv) trammel net: striped red mullet (M. surmuletus); (v) trammel net: cuttlefish (Sepia officinalis); (vi) longline: dentex (Dentex dentex); (vii) longline: red scorpionfish (Scorpaena scrofa); and (viii) trammel net: spiny lobster (Palinurus elephas). The fishing tactics targeting dolphinfish, transparent goby, and squid are practically monospecific, having very low by-catches. The remaining fishing tactics, by contrast, yield landings with comparatively important quantities of by-catch species. Altogether, those eight target species have accounted for $52 \%$ in terms of landings and $71 \%$ in terms of incomes of the SSF. The number of boats has decreased noticeably during the last 25 years in the whole Archipelago, from about 600 units in 1990 down to 254 units in 2013. Currently (2014), the official census of the SSF in the Archipelago includes a total of 340 fishermen and 265 boats. In Mallorca, there are a total of 147 vessels and 202 fishermen.

The decrease observed in the number of vessels in both the BTF and SSF is mainly related to the low attractiveness of fishing to young people, who prefer working on the touristic sector. In spite of such a decrease of fishing units, the fishing capacity has remained relatively constant owing to the concomitant increase of mean engine power (Figure 1). In fact, the landings of the main fisheries (BTF, SSF, purse-seine, and pelagic long-line) did not show important fluctuations during the last 15 years and the total landings from the Balearic Islands have not shown any clear trend during the last 75 years (Figure 2).
Due to the high number of recreational fishers in the Balearic Islands, its impact on the marine ecosystems and biological resources cannot be ignored. It was estimated that between 5 and $10 \%$ of the Archipelago population were recreational fishers (Morales-Nin et al., 2005, 2008). Total annual catches from Mallorca, which included 60 species of fishes and cephalopods, ranged between 1,200 and 2,700 t, accounting for 30-65\% of the official commercial landings (4,000 t per year). Based on these figures and the fact that recreational fishing shares with the SSF some of its main target species, it is essential to incorporate information on catches of this fleet when assessing and managing fishery resources from the Balearic Islands.

\section{Demersal Fishing Grounds}

The fishing grounds exploited by the demersal fisheries from the Balearic Islands are characterized by the presence of sensitive (SH) and essential fish (EFH) habitats, especially on the coastal continental shelf. The fishing grounds traditionally exploited by the BTF overlap with red algae beds including maërl and Peyssonnelia beds (Ordines and Massuti, 2009), which are considered a SH (protected under European fishing regulation EC No 1967/2006 of 21 December 2006) and an EFH (Ordines et al., 2015), respectively. The crinoid beds, also considered an EFH (Colloca et al., 2004; Ardizzone, 2006), dominate certain areas of the deep shelf, primarily between 120 and $200 \mathrm{~m}$ depth. Studies carried out in the Balearic Islands confirm the importance of these habitats in structuring demersal resources assemblages (Ordines and Massuti, 2009; Ordines et al., 2009). These studies have shown that benthic biogenic habitats such as maërl and Peyssonnelia beds not only affect the distribution of demersal resources, but also favors its individual physiological condition, allowing them to afford critical life stages such as 

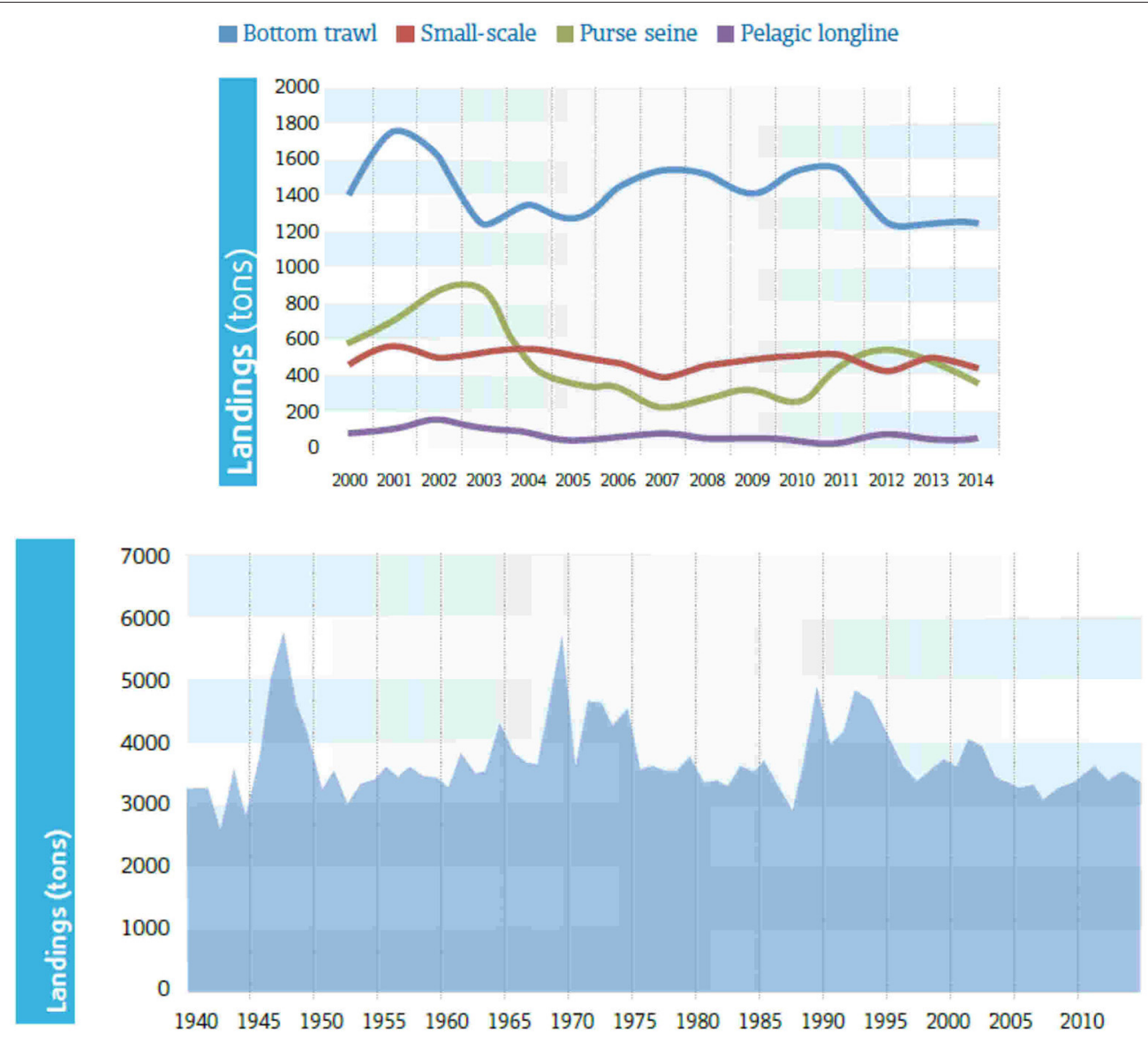

FIGURE 2 | Landings of the main fishing fleets from Mallorca between 2000 and 2014 (above) and total landings from the Balearic Islands during the last 75 years (below).

reproduction with more lipid reserves than individuals living in bare sandy bottoms (Ordines et al., 2011, 2015). These habitats constitute "living bottom structures" that enhance the three-dimensional complexity of benthic communities and its productivity, providing refuge for small-sized species and juvenile individuals of important fishing resources (Ordines et al., 2009).

The presence of these benthic habitats highlights the need to go toward multispecies and ecosystem-based assessment and management of demersal fisheries in the Balearic Islands. Thus, fishery management on the continental shelf requires the development of technical measures to protect benthic communities, which could also benefit demersal resources populations by reducing the direct impact of fishing mortality on crucial life stages (juveniles and spawners) and the indirect impact of fishing represented by the loss of $\mathrm{SH}$ and $\mathrm{EFH}$.

\section{Stock Status}

The exploitation state of the BTF target species was available from stock assessments carried out by some of the authors in the framework of different STECF and GFCM working groups. As there was not available information on the stock status of the target species of the SSF, they were assessed with surplus production models using the ASPIC software (Prager, 2004). For details on the assessment methods used, see references in Table 1.

Table 1 compiles the total number of BTF stocks from the Balearic Islands assessed up to now, highlighting the four main target species. Hake shows the worst stock status, with current fishing mortality $\left(\mathrm{F}_{\mathrm{c}}\right)$ being more than seven times the biological reference point $\left(\mathrm{F}_{0.1}\right)$. The MSY for striped red mullet, hake, Norway lobster, and red shrimp stocks would be achieved with effort reductions of 23, 71, 26, and 40\%, respectively (Merino et al., 2015).

Surplus production models were used to assess the eight target species of the SSF (Table 1) with the exception of the dolphinfish. The highly migratory behavior of this species prevents the use of stock assessment methods at local scales such as in our case (STECF, 2013), whereby the exploitation status of dolphinfish was not assessed. Except striped red mullet and squid, all other stocks are currently overexploited and the MSY would be achieved with the following effort reductions (Quetglas et al., 2016): spiny lobster (53\%), red scorpionfish (51\%), dentex (50\%), transparent goby (35\%), and cuttlefish (21\%). 
TABLE 1 | Stock status indicators of demersal species taken by the bottom trawl (BTF) and small-scale (SSF) fisheries from the Balearic Islands showing the current fishing mortality $\left(F_{C}\right)$, the reference biological point ( $F_{R P}: F_{0.1}$ for BTF, $F_{M S Y}$ for SSF), the ratio between them $\left(F_{c} / F_{R P}\right)$, and the information source.

\begin{tabular}{llrrrl}
\hline Fishery & Stock & Fc & $\mathbf{F}_{\mathbf{R P}}$ & $\mathbf{F c}_{\mathbf{R P}}$ & Sources \\
\hline BTF & Black-bellied angler & 0.84 & 0.08 & 10.5 & STECF, 2014 \\
& European hake & 1.15 & 0.15 & 7.7 & GFCM, 2014 \\
& Red mullet & 0.93 & 0.15 & 6.2 & GFCM, 2014 \\
Striped red mullet & 0.51 & 0.17 & 3.0 & GFCM, 2014 \\
Red shrimp & 0.42 & 0.24 & 1.7 & GFCM, 2014 \\
Norway lobster & 0.29 & 0.17 & 1.7 & STECF, 2014 \\
Common octopus & 0.47 & 0.32 & 1.5 & STECF, 2012 \\
Deep-water pink shrimp & 0.77 & 0.62 & 1.2 & STECF, 2013 \\
Cuttlefish & 0.44 & 0.41 & 1.1 & Quetglas et al., 2015 \\
\hline \multirow{2}{*}{ SSF } & Dentex & 0.26 & 0.13 & 2.0 & Quetglas et al., 2016 \\
& Red scorpionfish & 0.32 & 0.16 & 2.0 & \\
Striped red mullet & 0.10 & 0.14 & 0.7 & \\
Transparent goby & 0.13 & 0.08 & 1.5 & \\
Spiny lobster & 0.31 & 0.15 & 2.1 & \\
Cuttlefish & 0.18 & 0.14 & 1.3 & \\
Squid & 0.16 & 0.16 & 1.0 & \\
& & & &
\end{tabular}

Target species are in italics.

\section{Bioeconomic Analysis}

In order to achieve conservation and economic objectives, deciding the correct dimension of fisheries, and their activity is paramount. For this purpose, the impact on fisheries performance indicators of the following four management scenarios were tested for the BTF and SSF: (i) a projection of current conditions (Control); (ii) the main target species will be located in the green quadrant of a Kobe plot, that is $\mathrm{F}<\mathrm{F}_{\mathrm{MSY}}$ and $\mathrm{B}>\mathrm{B}_{\mathrm{MSY}}$ (All Green, AG); (iii) the maximum aggregated catch (Multispecies Maximum Sustainable Yield, MMSY) of the target species will be sought; and (iv) the Maximum Economic Yield (MEY) of the fishery will be achieved. The bioeconomic analyses were carried out using the MEFISTO 3.0 bio-economic simulation model (Mediterranean Fisheries Simulation Tools, www.mefisto.info), which was specifically designed to address management issues under the Mediterranean regulation system (Lleonart et al., 2003). For details on the bioeconomic analyses, see Merino et al. (2015) and Quetglas et al. (2016) for the BTF and SSF, respectively.

In order to reach the AG scenario (all four target species would be exploited below their MSY) current fishing effort of trawlers from Mallorca would have to be reduced by $71 \%$; with this scenario, hake would be at $\mathrm{B}_{\mathrm{MSY}}$ and the biomass of striped red shrimp, red mullet, and Norway lobster would be above 1.5 times the $B_{\text {MSY }}$. To achieve the MMSY scenario, the activity of trawlers would have to be reduced by $57 \%$; under these conditions, hake would continue to be overexploited but at more secure levels than in the Control scenario. Currently, the BTF from Mallorca generates $€ 1.29$ million of net profits. In order to achieve the MEY, which the model situates at $€ 1.90$ million, the fishing effort has to be reduced by $48 \%$ ( $\sim 115.44$ fishing days per year). Under this scenario, hake would continue to be overexploited while the other three species would remain at secure levels, with red shrimp very close to full exploitation. Lower, moderate reductions of fishing effort such as reducing from 5 to 4 working days per week, would also bring notable profit increases ( $>€ 1.60$ million).

The effort reductions required to achieve sustainable exploitation of the SSF are much lower than those foreseen for the BTF. According to the bioeconomic model results, if all seven target species of the SSF were exploited below their MSY (AG scenario), current fishing effort would have to be reduced by $53 \%$. If the aggregated catch from all species was to be maximized (MMSY), the activity of the SSF would have to be reduced by $38 \%$. In case the maximum economic yield (MEY) would have to be attained, reductions required in fishing effort would be markedly lower (28\%). Under current economic conditions and current fishing effort, the SSF generates $€ 2.86$ million of net profits. With the parameters used in our modeling, total profits would slightly decrease down to $€ 2.82$ million in the AG scenario and would reach as much as about $€ 3.3$ million under the MMSY ( $€ 3.29$ million) and MEY (€3.34 million) scenarios. The AG scenario would lead all stocks to the bottom-right area, where dentex, scorpionfish, and spiny lobster would be at $B_{\text {MSY }}$ while the biomass of the remaining stocks would range between 1.3 and 1.7 times the $\mathrm{B}_{\mathrm{MSY}}$. Under the MMSY and MEY scenarios, three stocks (dentex, scorpionfish, and lobster) would continue to be overexploited but at more secure levels than in the control scenario.

\section{Decision Support Tables}

The main results of the aforementioned bioeconomic analyses are the basis of DSTs, graphical tables that reflect the effects and trade-offs of implementing different MSY options on ecosystem, economic, and social constraints and with particular focus on the risk of exceeding acceptable levels for these constraints. The DSTs have been designed to convey complex, alternative management scenarios in a simple and understandable way to support fisheries managers in their decision making. There were constant feedback and several meetings with local stakeholders to outline and design the DSTs.

The DSTs were prepared for the BTF and SSF separately and include three different management scenarios (Figures 3, 4): (i) the current situation, which is considered unsustainable given that all (BTF) or most (SSF) stocks are over-exploited; (ii) the MEY scenario predicted by the bio-economic model, which was considered unfeasible by the fishermen owing to the very high reductions in fishing effort required; and (iii) an intermediate scenario in between these two previous, extreme situations in which the figures (effort, catch, economic value) are the average between the current and the predicted MEY scenarios.

The management scenario agreed with stakeholders includes the reductions of fishing effort necessary to obtain the catches shown in the intermediate scenario. The benefits of such fishing effort reductions would be two-fold. Firstly, an improvement in the exploitation status of the different target stocks and hence on the demersal ecosystems exploited by the BTF and SSF. Secondly, an improvement in the viability of the fishing 


\section{West Mediterranean DST: Bottom Trawl Fishery}

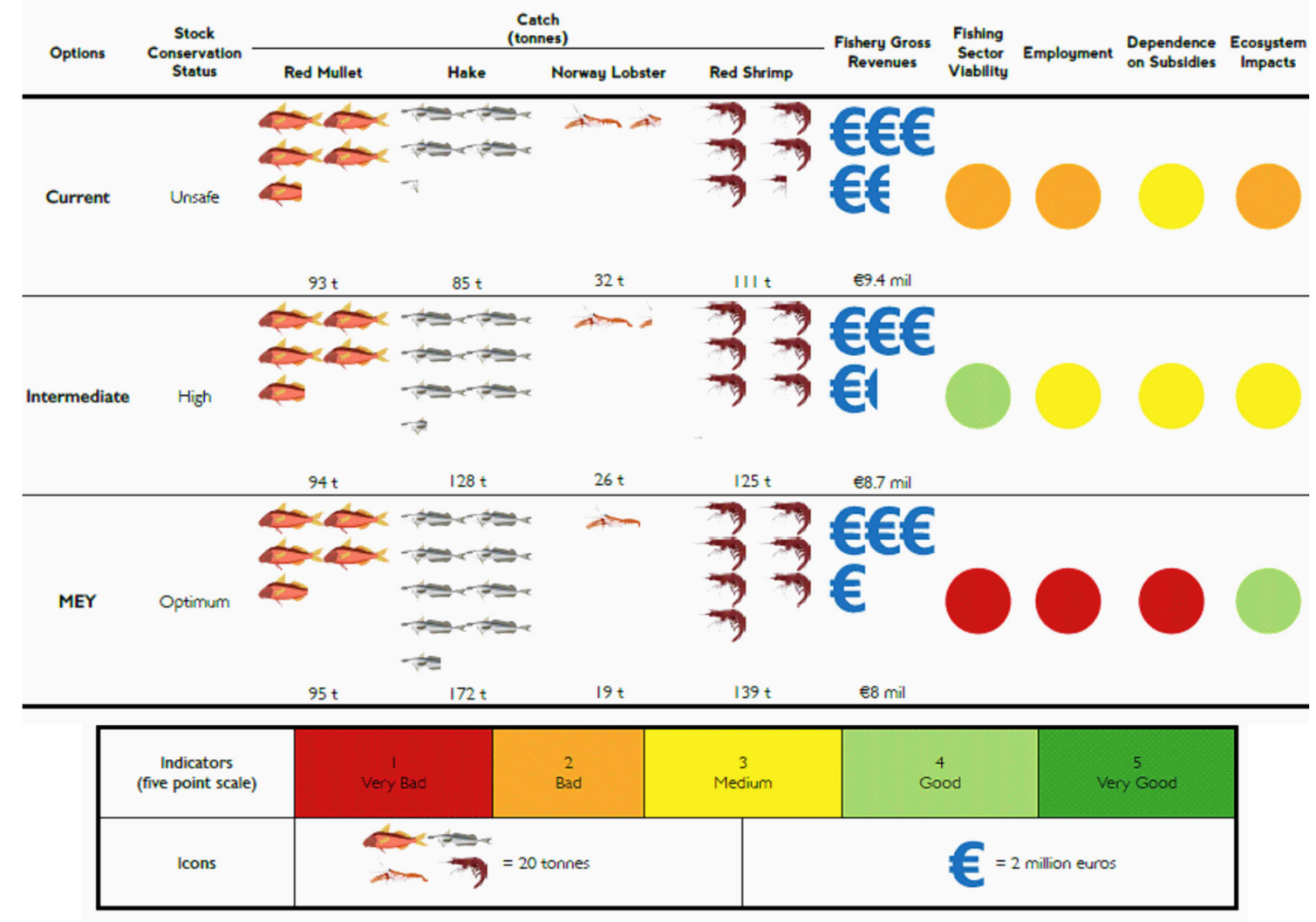

FIGURE 3 | Visualized form of the Decision Support Table from the bottom trawl fishery.

industry, primarily by means of reducing fishing costs in terms of substantial reductions in fuel consumption.

\section{Fish Price Analysis}

Together with the increase on fuel price, Mallorca fishermen, as elsewhere in the Mediterranean, have to cope with a constant decrease of the fish price (due to strong market competence with imported seafood) which jeopardizes its economic viability. According to stakeholders, the viability of the fishery in the Balearic Islands depends on marketing aspects (increasing fish/fuel price ratio) rather than on the exploitation status of the main stocks. Consequently, marketing improvements in the fishing industry should be done in order to increase the economic value of the main species. In order to investigate improvements on the commercialization scheme, price formation in the BTF and SSF were analyzed using a 15 years' database (2000-2014) of daily sale bills providing catches and prices per day and vessel. Factors influencing the price formation were estimated using hedonic analysis, which specifies a product price as a function of different attributes.

The average price of fish landed by the BTF at the Mallorca auction was $6.1 € / \mathrm{kg}$, with a peak of $7.3 € / \mathrm{kg}$ in 2005 followed by a gradual decrease since then down to the current $6.4 € / \mathrm{kg}$ (a $12 \%$ drop measured in nominal prices and 26\% if constant 2014 price are considered). On the other hand, the fuel price increased a $45 \%$ along the same period, causing a constant decrease of the fish/fuel price ratio. Compared to the BTF, fish prices from the SSF are in general higher $(7.1 € / \mathrm{kg}$ average fish price) and do not suffer important reductions; the average fish price peaked at $9.5 € / \mathrm{kg}$ in 2007 and has slightly decreased since then down to the current $9.1 € / \mathrm{kg}$ (only a $4 \%$ drop measured in nominal prices). Owing to its high commercial interest, red shrimp is the best option to implement new commercialization strategies for the BTF. Sales of red shrimp represent $40 \%$ of the total income from the BTF and $70 \%$ of the incomes coming from the four main target species.

Size was the most important factor affecting seafood prices, especially in the BTF where the prizes of small-sized individuals of red shrimp and Norway lobster are 71 and $66 \%$ lower than the prices fetched by the largest commercial category. Therefore, improving the BTF selectivity would be efficient in terms of enhancing fleet's revenues and profitability. The day of the week is also important (lowest prices in Tuesdays, highest prices in Fridays-Saturdays), whereby reducing the fishing days per week as a management measure should target those days with lower prices to minimize losses. The season is also relevant, with luxury 


\section{West Mediterranean DST: Small-Scale Fishery}

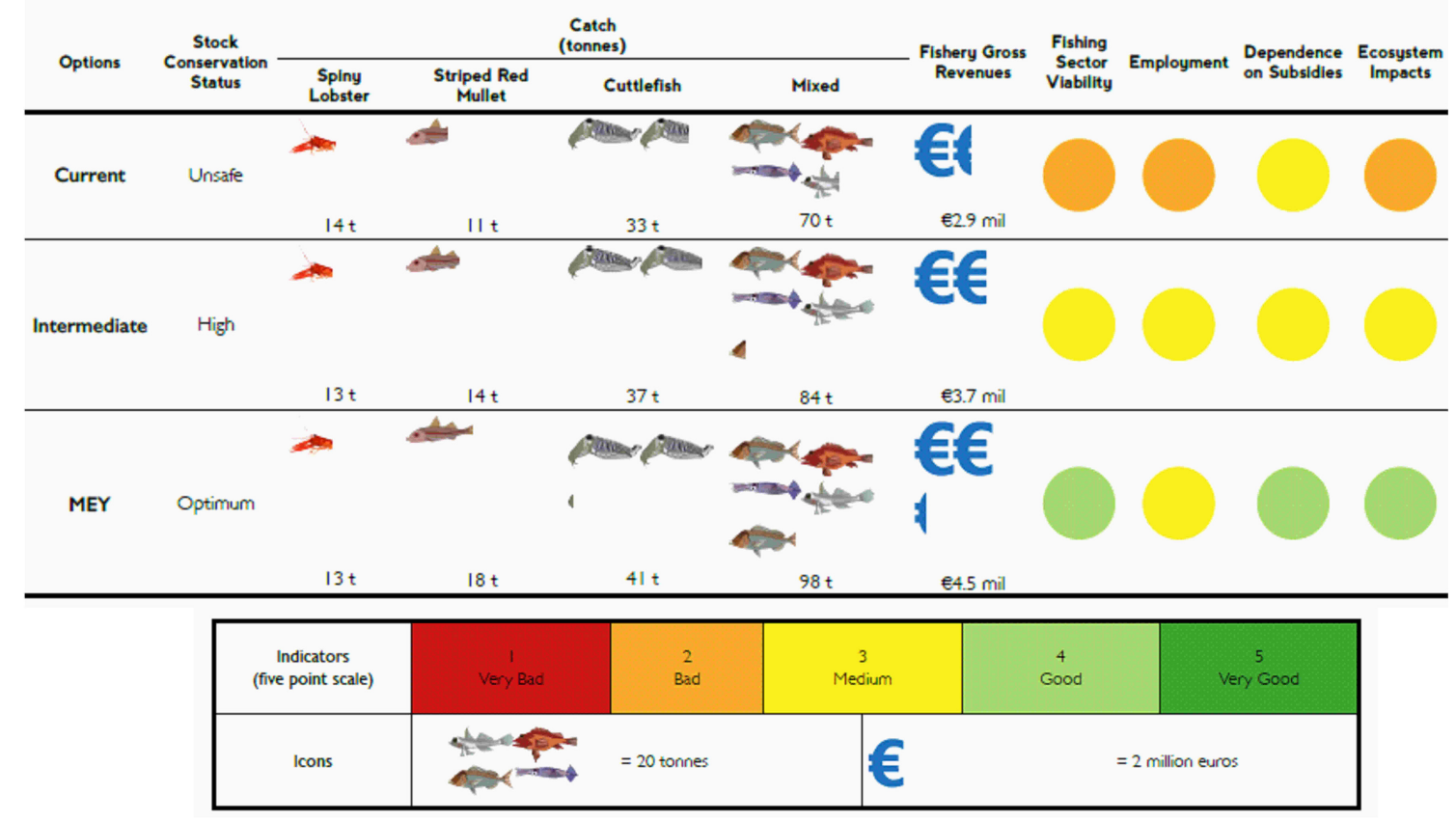

FIGURE 4 | Visualized form of the Decision Support Table from the small-scale fishery.

products such as red shrimp or lobsters presenting high peaks during Christmas and summer periods.

\section{Management Proposals}

A set of management proposals were outlined based on the main results obtained in all previous analyses, together with discussions hold with representatives of the two main local stakeholders during the 4 years of the project development. As aforementioned, management proposals from the NGO Oceana were also reviewed from the available literature (Carreras and Cornax, 2011). Proposals for both the commercial and recreational fisheries were included (Figure 5). The management actions proposed to improve the status of the exploited stocks and the commercialization of fish were split into the two following sections: (i) exploitation model; and (ii) business model.

\section{Commercial Fisheries \\ Exploitation model}

The main objective in this point is to optimize the fishing effort by means of reducing the fishing activity and using more selective gears.

\section{General management actions.}

Measures under this section apply indistinctly to both commercial fisheries, the BTF, and SSF.

(A) Compliance of current fishery regulations

An effective management should begin with a full compliance of fishery regulations. Consequently, efforts should be put to ensure this compliance from the scratch and a continuous surveillance established to ensure its fulfillment with time. Not doing it might prevent the success of further management measures.

(B) Fishing effort reductions

Owing to the sharp decrease in the number of fishing units in both fisheries, further reductions are not contemplated in order to ensure the viability of the fishing industry. If the decreasing rate observed in the BTF from Mallorca during the last 25 years is maintained, the fleet would disappear in less than 25 years (Figure 6). As explained below, the actions intended to reduce the fishing effort will include, for instance, reducing the time at sea.

(C) Review and update the minimum landing size (MLS) for some species

In the Mediterranean, the current landing obligation (Article 15 of CFP) only applies to a reduced list of species having MLS. To ensure the sustainability of the fishing exploitation, those MLS should be equal, or higher than, the size at first maturity $\left(\mathrm{L}_{50}\right)$. As $\mathrm{L}_{50}$ is the size at which the $50 \%$ of the population has reached the sexual maturity, this measure will allow that about half of the population of commercial species can reach reproduction at least once. Paradoxically, this is not the case in many stocks in the Mediterranean.

(D) Conservation of essential fish habitats

These measures could be based on spatial (and/or temporal) closures in addition to the already existing net of marine protected areas in the Balearic Islands. Areas and periods of especial interest for hatching and recruitment of the main commercial species should be avoided by fishermen, 


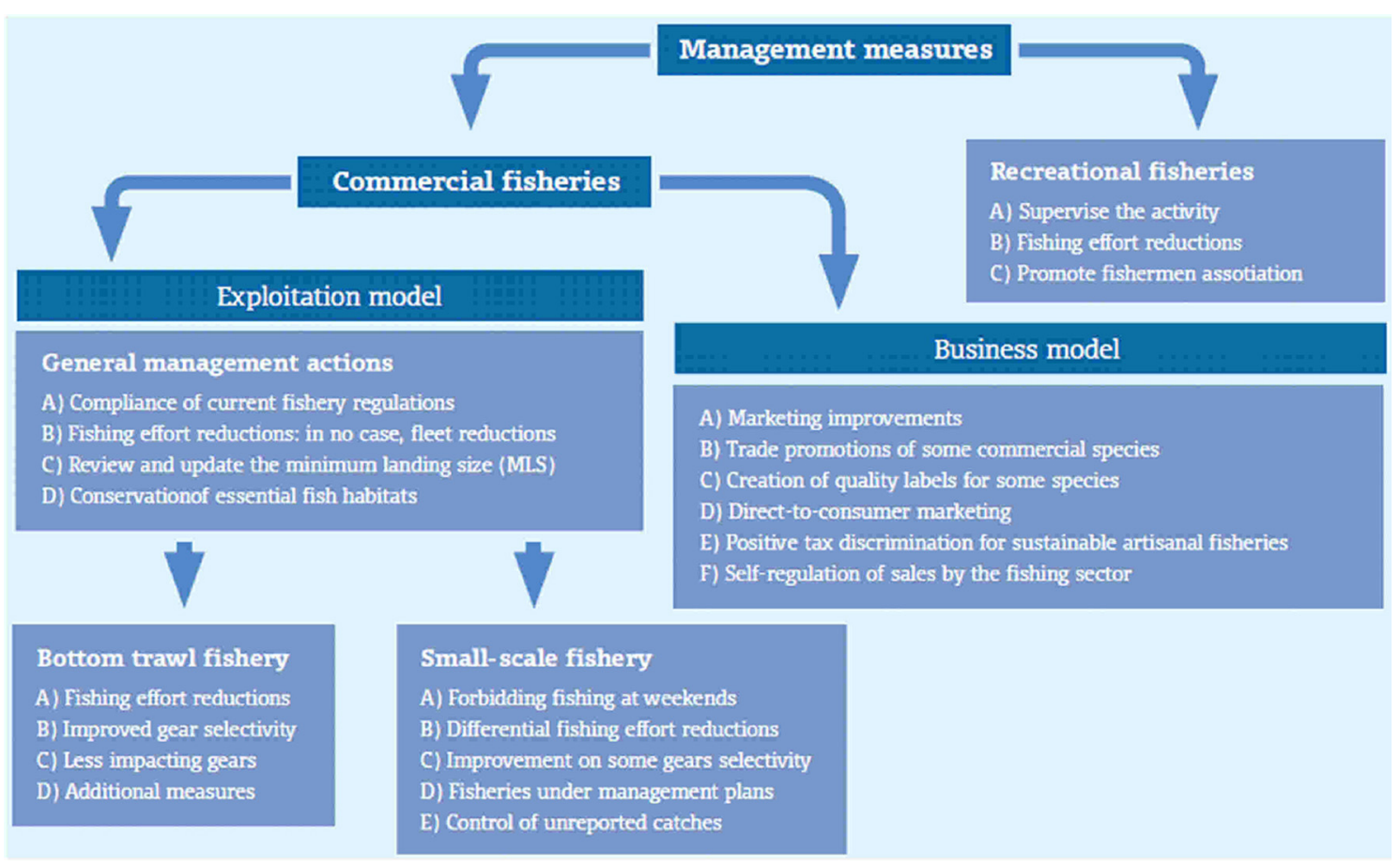

FIGURE 5 | Scheme of the management measures proposed in this study for the demersal fisheries from the Balearic Islands (western Mediterranean).

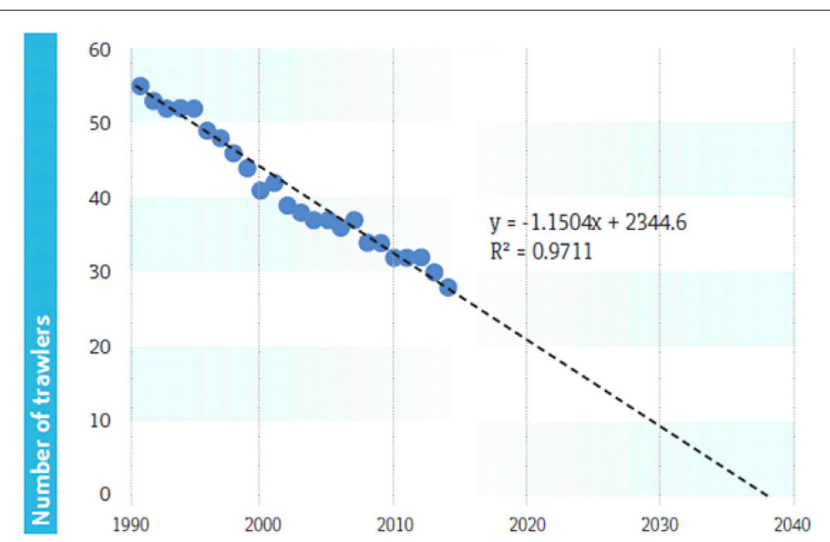

FIGURE 6 | Number of bottom trawlers in Mallorca during the last 25 years with the corresponding linear regression fit and its extrapolation until the fleet disappearance (2038).

preferentially by those using less selective gears such as the BTF. Such avoidance should be based on scientific studies, complemented with fishermen knowledge, to map the spatiotemporal distribution of fish and hatching and nursery areas.

\section{Bottom trawl fishery.}

(A) Fishing effort reductions

Fishing effort reductions should be based on reducing time at sea, either in terms of hours per day or days per week.
Moving from the current 5 days per week to 4 would imply not only reducing the fishing effort by $20 \%$ but also reducing the exploitation costs, primarily due to fuel saving. In experiences undertaken in Alicante, results showed that the losses from banning on Wednesday might be compensated by price increases and reductions of exploitation costs (Samy-Kamal et al., 2015). In case the reductions of fishing effort were not applied in terms of days per week, an alternative option could be decreasing the total number of working hours per day.

Given that bottom trawlers operate on different bathymetric strata depending on the target species, differential effort reductions should be put in practice according to the exploitation status of each single stock (Table 1). This would not imply stopping the fishing activity, but a sort of diversification of the fishing exploitation to focus on healthier stocks until the recovery of the most impacted ones.

(B) Improved gear selectivity

According to recent studies (Colloca et al., 2013; Vasilakopoulos et al., 2014), improvements in the fisheries selectivity would be more effective than reducing the fishing effort in order to manage Mediterranean BTFs. Although the recent change in mesh geometry (Council Regulation No. 1967/2006) improved the gear selectivity, it was not effective for important by-catch resources whereby additional technical improvements are still needed (e.g., square mesh panels and sorting grids). 
(C) Less impacting gears

Technical modifications to reduce the physical impact of BTF gears on the seabed are needed. The use of mid-water doors, shorter sweeps, and lighter nets has proved successful, since these modifications allowed obtaining similar catches than those obtained with traditional gears but with a significant reduction of fuel consumption (Guijarro et al., submitted). Consequently, these modifications contribute to improve not only the ecological fingerprint through lower physical impact and lower $\mathrm{CO}_{2}$ emissions, but also the economic efficiency of the BTF.

(D) Additional measures

According to Oceana (Carreras and Cornax, 2011), the bottom trawl fishing on continental shelf grounds should be forbidden in the Balearic Islands because it is an ecologically (high physical impact on the bottom and high discard rates) and economically (low commercial value of catches and high fuel consumption) unsustainable fishery. To our view, however, this would not be a good measure. Firstly, it would concentrate the fishing activity to slope grounds where the main target species are Norway lobster and red shrimp, increasing the fishing effort over resources that are already in an overexploitation status. Secondly, the absence of fishing resources from the continental shelf grounds in the market chain would make difficult the maintenance of the marketing of local, fresh seafood products from the Balearic Islands.

\section{Small-scale fishery.}

(A) Forbidding fishing at weekends

Under current regulations, the SSF is allowed to fish from Monday to Saturday. Catches taken on Saturday, however, cannot be commercialized until next Tuesday whereby they are alternatively sold to consumers directly. To avoid this commercialization problem, together with reducing the fishing exploitation of the SSF, fishing might be forbidden during the weekends, reducing the weekly fishing activity from Monday to Friday. According to the Fishery Association of the Balearic Islands, preliminary experiences with different fisheries (e.g., dolphinfish, picarel, and transparent goby) have proved to be positive, both for the resource and its commercialization.

(B) Differential fishing effort reductions

As in the case of the BTF, differential fishing effort reductions might be implemented for the SSF since this fleet operates on different target species with contrasting exploitation states (Table 1). As above, this would not imply stopping the fishing activity, but a sort of diversification of the fishing exploitation to focus on healthier stocks until the recovery of the most impacted ones.

(C) Improvements on some gears selectivity

Recent studies carried out in the Balearic Islands (Goñi et al., 2013) demonstrate that the selectivity of the SSF can also be improved. These studies focused on the trammel net fishery targeting the spiny lobster and showed that using experimental nets of polyethylene multi-monofilament, instead of the traditional ones of polyamide multifilament, reduced both the number of lobsters below the MLS and the discards of rodoliths. Further improvements such as replacing the trammel net by gillnet, increasing the mesh size, or reducing the soaking time should also be investigated.

(D) Tagging catches

Recent studies in the Archipelago have demonstrated the feasibility of using V-notch marks on the tail flipper of breeding female spiny lobsters (Goñi et al., 2013). These marks are successfully used in other decapod crustacean fisheries such as in the North Atlantic to identify individuals under the legal size and breeding females (Telsnig, 2013) and in the Western Australia to avoid the commercialization of recreational catches (Acheson and Gardner, 2011). The results obtained so far with lobsters suggest that V-notch marks would be an effective measure to protect breeding females returned at sea, thus increasing the reproductive potential of the population.

(E) Fisheries under management plans

Some SSF, such as the transparent goby, are already integrated under management plans. According to the Fisheries Association, integrating all SSF under management plans will be highly beneficial to improve not only the exploitation state of the main target species but also its marketing and commercialization. For this purpose, management plans have to be associated with quality labels (ecolabels) for the main target stocks, which should be a guaranty of seafood obtained through sustainable exploitation.

(F) Control of unreported catches

Sale of fish outside the official market is an important issue in SSF (25\% of the reported catch; Carreras et al., 2015), especially in species with high commercial value such as dentex, red scorpionfish, and spiny lobster. Together with its effects on commercialization, unreported catches are highly detrimental for the assessment and management of SSF. This reinforces the need to sensitize the fishing sector about the importance of providing scientists the best data possible in order to help improving the stock assessment and management.

\section{Business model}

The main objectives here are achieving reductions in exploitation costs, primarily fuel consumption, together with increases in revenues by means of marketing actions. It should be noted that the measures listed in the previous section will help addressing those objectives, since most of them entail fuel savings due to reductions of fishing activity and fish price increases as a result of lower supply. Although this issue demands specialized socio-economic studies, some general actions are listed below.

(A) Marketing improvements

In order to increase the prices of some species, especially those with the highest commercial value, marketing campaigns should be launched. As aforementioned, red shrimp is the best option to implement new 
commercialization strategies for the BTF. However, there are many other examples from the SSF since it catches different species of fish (e.g., grouper, John Dory) and crustaceans (e.g., spiny lobster) of high commercial value.

(B) Trade promotions of some commercial species

The globalization of trade markets has changed consumer habits and affected seriously the commercialization of fresh Mediterranean seafood. This calls for trade promotions to potentiate local products, either by recovering the now abandoned traditional consumption of some species such as the picarel (Spicara smaris) or promoting other by-catch species both at home and at restaurants.

(C) Creation of quality labels for some species

Today, there is an increasing number of markets demanding quality labels or ecolabeled products (e.g., Marine Stewardship Council-MSC). For many consumers, the quality and freshness of seafood, and even the environmental credibility, plays an increasing role in purchasing decisions. In a highly touristic place such as the Balearic Islands, this formula should be enhanced, especially for high-valued species such as spiny lobster, John Dory, or red scorpionfish.

(D) Direct-to-consumer marketing

Direct marketing in the Balearic Islands may have several advantages: (i) higher incomes to fishermen by avoiding unnecessary retailers; (ii) lower transportation costs since the fish will not be sent to the central auction wharf in Palma; (iii) fresher fish, which might imply higher prices, as a result of reducing the market chain. Direct marketing, however, should be accompanied with a reliable control system in order to avoid black market and unreported catches.

(E) Positive tax discrimination for sustainable artisanal fisheries This measure would be directed to favor artisanal fisheries, primarily those using more selective gears such as traps, in front of more impacting fisheries such as bottom trawl. The use of traps in some specific fisheries, such as the spiny lobster fishery, was a common practice in the Balearic Islands some time ago, but it was completely abandoned during the early 2000 s for more impacting, profitable gears such as trammel nets.

(F) Self-regulation of sales by the fishing sector

At the fishing industry own initiative, this measure is already in place for some SSF, such as dolphinfish in the whole Mallorca and spiny lobster in some specific ports. Setting daily quotas for dolphinfish and both seasonal quotas and a constant mean price in the case of spiny lobster is intended to render higher economic yields to fishermen. This measure could then be extended to other target species, either belonging to the BTF or the SSF.

\section{Recreational Fishery}

(A) Supervise the activity

Currently there is not an official record of catches from the recreational fishery in the Balearic Islands. However, the importance of this fishing practice makes essential incorporating these catches when assessing and managing the fishery resources from the Archipelago. It is also necessary to improve the supervision of the activity at sea in order to ensure the compliance of current regulations, together with controlling the final destination of the catches as they cannot be commercialized in any case.

(B) Fishing effort reductions

The effort reductions necessary to ensure a sustainable management of marine resources cannot fall exclusively on the professional sector, but should also apply to the recreational fishery. Fishing effort limitations could be carried out through reductions in the number of allowed fishing days and the maximum authorized catches in order to adapt them to the increasing number of practitioners in recent decades (there are about 70 recreational fishers for every professional fisherman). Currently there is no limitation of activity, except for temporary closures for some species (Xyrichthys novacula and Seriola dumerili). The fishing effort could also be reduced by activity limitations in certain areas, such as the marine reserves where, furthermore, the spearfishing should be completely banned. In the case of spearfishing, the prohibition of using artificial light would increase the chances of survival of fish seeking refuge as a defense strategy.

(C) Promote fishermen associations

Recreational fishermen associations would facilitate the collaboration and involvement of the sector in the management of this fishing activity, especially in providing information about their catches.

\section{Monitoring}

Once the management measures are put into force, a monitoring plan should be established in order to assess the effects of those measures and the actions to be undertaken if the expected results (improved exploitation status of target stocks) are not achieved. As aforementioned, an effective management should begin with a full compliance of fishery regulations. Consequently, an effective and reliable control system should be set up to ensure fishermen compliance with both the fishery regulations and the management actions contemplated within this RIP.

A scientific surveillance system to monitor the effects of the management measures is also needed. Such a scientific monitoring would use different sampling and data sources to assess the RIP progresses, primarily the exploitation state of the main target species. Currently, this monitoring in European waters is implemented through the Data Collection Framework (DCF, datacollection.jrc.ec.europa.eu/), whereby the member states collect, manage, and make available a wide range of fisheries data needed for scientific advice. This data collection encompasses:

(i) Fishery-dependent data: it includes time series of landings and fishing effort obtained from fishery statistics, along with scientific sampling at fish markets or on board commercial vessels to analyse the catch species composition and the size structure of the main target stocks. The availability of these data sources fully depends on the collaboration of the fishing sector (Guijarro et al., 2012a). 
(ii) Fishery-independent data: it refers to scientific sampling on board research vessels. From 1994 on, the EU and the participating member states are co-financing the MEDITS (MEDIterranean Trawl Surveys) programme. This programme aims to conduct coordinated scientific bottom trawl surveys in the Mediterranean European waters, covering trawlable grounds over the shelf and upper slope from 10 to $800 \mathrm{~m}$ depth (Bertrand et al., 2002). Scientific surveys following the MEDITS protocol started in the Balearic Islands in 2001, being included in the MEDITS programme in 2007. Since then the fishing grounds (50-800 m) around Mallorca and Menorca are surveyed annually during late spring or early summer. The data collected in these surveys allows assessing the health of the ecosystems and living resources from the Balearic Islands using information independent from the fishing activity.

Using all these information sources, the surveillance system will assess the exploitation estate of the main target stocks (Table 1) and present the results to the suitable international forums, the GFCM, and STECF.

Conservation reference points consistent with the objective of achieving the MSY target by 2020 will be set out for all assessed stocks. Fishing mortality (F) and biomass (B) relative to those foreseen under the MSY will be used: $F / F_{M S Y}$ and $B / B_{M S Y}$ respectively. As a general consensus, stocks with $\mathrm{B} / \mathrm{B}_{\mathrm{MSY}}<1$ and $\mathrm{F} / \mathrm{F}_{\mathrm{MSY}}>1$ are indicative of an overexploitation state, while $\mathrm{B} / \mathrm{B}_{\mathrm{MSY}}>1$ and $\mathrm{F} / \mathrm{F}_{\mathrm{MSY}}<1$ are indicative of an underexploitation state. Given that the main objective is to exploit the target stocks at MSY, corrective measures will be applied in case the assessments reveal overexploited stocks.

In order to assess not only the main target stocks but also other species or taxonomic groups, together with different ecosystem compartments, additional conservation indicators will be used. This assessment will allow revealing population trends in both commercial (by-catches) and non-commercial (discards) species and also taxonomic groups with special sensitivity to fishing exploitation such as elasmobranchs (Quetglas et al., 2016). To this end, conservation indicators agreed within the Marine Strategy Framework Directive (MSFD), which aims to achieve Good Environmental Status (GES) of the EU's marine waters by 2020 and to protect the resource base upon which marine-related economic and social activities depend, will be monitored. The preliminary assessment of the Balearic Islands area under the MSFD is currently available (MSFD-Levantino Balear) and will be monitored in the future according to the MSFD road map.

Assessing the complexity of exploited ecosystems using a variety of indicators demands the use of summarizing approaches such as the traffic lights methodology, which has already been used in the Balearic Islands (Guijarro et al., 2011, 2012b). This approach was firstly proposed as a type of precautionary management framework suitable for use in fishery assessment in data-poor situations (Caddy, 2002), but it can also be used to assess the status of all stocks whether rich or poor in data (Halliday et al., 2001). It has been applied for single- and multispecies assessments both in the Atlantic and the Mediterranean (e.g., Caddy et al., 2005; Ceriola et al., 2007) and appears to be more precautionary than traditional stock assessment methods (Koeller et al., 2000). As above, if this approach reveals negative trends in population or ecosystem indicators, corrective measures will be designed.

\section{DISCUSSION}

Recent reviews have revealed the serious overfishing of most Mediterranean stocks (Colloca et al., 2013; European Commission, 2014; Vasilakopoulos et al., 2014), which is in contrast with the improvement observed in other European areas (European Commission, 2014). The reasons for such a contrasting situation probably lay in the governance systems of these regions rather than in the nature of their resources (Smith and Garcia, 2014). Fisheries management in the Mediterranean has been ineffective, necessitating urgent reforms of the management measures aiming to guarantee the sustainability of resources. This reform should not only focus on reducing the exploitation rate and on improving selectivity (Colloca et al., 2013; Vasilakopoulos et al., 2014) but also on the political and socioeconomic changes beyond fishery management (Smith and Garcia, 2014). The new EU CFP constitutes an excellent opportunity to introduce the changes needed for such a reform, as it has as a main objective ensuring that fishing activities are environmentally sustainable in the long-term by means of the implementation of the EAFM. This approach demands the development of management strategies for the entire social and ecological system, where humans are a fundamental part of the ecosystem (Ramirez-Monsalve et al., 2016). Managing human activities should be organized at the appropriate geopolitical level matching the scale of the ecosystem, hence organizing marine management at the regional level (van Hoof, 2015). Harvest strategies, including HCRs, lie at the heart of these management developments, and can facilitate a fisheries governance system where regulators and fishers work together to decide on overall harvest (Kvamsdal et al., 2016).

In this paper, we outlined a harvest strategy for the multispecific demersal fisheries from the Balearic Islands (western Mediterranean) aimed at optimizing socioeconomic and ecosystem objectives in the framework of Regulation $\mathrm{N}^{\circ}$ $1380 / 2013$. This harvest strategy is therefore focused on the general objective of the new CFP to achieve the sustainable exploitation of marine living resources establishing multiannual plans under the regionalization principle.

To our view, the most urgent measure for fisheries management in the Mediterranean should be a clear determination of law enforcement by riparian countries, which would probably do unnecessary implementing new, more restrictive regulations than the currently existing ones. It is a non-sense setting fishing regulations if its fulfillment will not be controlled, as occurs, for instance, with the limitation of maximum gear power for bottom trawlers, the maximum length of nets for the small-scale fishery, and the conservation of maërl grounds.

The Mediterranean context (multispecies, multifleet) demands specific, bespoke measures suited to differences in 
the exploitation state, not only among the main stocks but also among different regions (regionalization principle). Managing human activities should be organized at the appropriate geopolitical level matching the scale of the ecosystem, hence organizing marine management at the regional level (van Hoof, 2015). Differential effort reductions in line with the status of each single stock should be used (Table 1), with the fishing exploitation focusing on healthier stocks until the recovery of the most impacted ones. Owing to its high overexploitation, stronger measures should be enforced for hake and even a recovery plan might be considered. In addition, the ecosystem-based fisheries management must integrate not only the main target stocks, but also relevant by-catch species (Ordines et al., 2014) and take into account the conservation of the habitats present on the fishing grounds (Ordines et al., 2015).

In the Balearic Islands (GSA05), the fishing effort has remained relatively low as compared to that in the nearby areas (Quetglas et al., 2012). The all-time maximum number of bottom trawlers in Mallorca, for instance, has been 70 units in 1977 and presently (2014) there are only 28 trawlers and some vessels leave the fishery every year. These values are clearly very far from the total number of vessels in GSA06, the adjacent area of the Iberian Peninsula where even some individual ports have more trawlers than all the ports of Mallorca combined. Trawl fishing exploitation in GSA05 is much lower than in GSA06, with the density of trawlers around the Balearic Islands being one order of magnitude lower than in adjacent waters (Massutí and Guijarro, 2004). As a result, the demersal resources and ecosystems in GSA05 are in a healthier state than in GSA06, which is reflected in Quetglas et al. (2012), Ordines (2015): (i) the size-structure of the main commercial stocks; (ii) the higher abundance and diversity of vulnerable species such as elasmobranchs; and (iii) the presence of some sensitive benthic habitats, some of them acting as essential fish habitats, which overlap with traditional fishing grounds. These differences among areas should be taken into account for fisheries management, avoiding the use of general measures for all areas. This is again in line with the regionalization principle and demands a shift in the modus operandi of the CFP from a traditional centralized top-down, command-control approach toward more regional-specific management which should be, in turn, developed and implemented with stakeholders in a spirit of co-management (Eliasen et al., 2015).

Despite the fishing effort of the BTF has remained relatively low in the Balearic Islands compared to nearby areas, the fishing exploitation has produced noticeable effects on the main demersal resources. As a result of fishing, some target stocks shifted from an early period of under-exploitation to overexploitation during the late 1970s or early 1980s (Quetglas et al., 2013). This change altered the population resilience of those stocks and brought about an increase in the sensitivity of its dynamics to the climate variability. These results reveal that the marine ecosystems from the Balearic Islands are also sensitive to changing environmental conditions, an issue of paramount importance in the framework of the current climate change. Consequently, the putative effects of global change should also be considered for regional fisheries management which, in turn, will demand an adaptive approach to face those changing conditions. In this sense, the ecosystem-based management is highly-equipped for climate change adaptation (Ogier et al., 2016). As multiple climate-driven changes can induce hardto-reverse shifts in regional ecosystems, the EAFM becomes a necessity rather than a precautionary approach (Marzloff et al., 2016).

In spite of representing the $85 \%$ of EU fleets (European Commission, 2014), SSF are under-represented, or directly neglected, in fisheries assessment and management agendas at national and supranational levels (e.g., Guyader et al., 2013). In the Myfish project, we have included a first in-depth analysis of the SSF from the Balearic Islands using data from official statistics (Quetglas et al., 2016), which are known to be underestimated in the Mediterranean owing to unreported catches (Coll et al., 2014; Pauly et al., 2014). As a consequence, output values of the stock status indicators and the bioeconomic modeling should be taken with care beyond tracking trends in the fishery. Sales of fish outside the official market are especially important in species with high commercial value such as dentex, red scorpionfish, and spiny lobster (Carreras et al., 2015), which are precisely the stocks showing the worst exploitation status. Unreported catches may result in underestimation of fishing mortality, leading to biased stock assessments that hamper achieving a sustainable exploitation (Punt et al., 2006; Bellido et al., 2011). This reinforces the need to sensitize fishermen about the importance of providing the best data possible to scientists in order to help improving the stock assessment and management. The problem of the underreported catches is compounded by the recreational fisheries, which share some of the main SSF target species. In the highly touristic Balearic Islands, where recreational catches represent $43 \%$ of the commercial ones (Morales-Nin et al., 2015), this activity might affect seriously the exploitation state of some target stocks. Recreational and competitive spear fishing have a sizeable impact on the depletion of large rocky bottom littoral fish (e.g., Epinephelus marginatus) and contributes to the non-profitability of some gears used by the SSF (Coll et al., 2004). Moreover, some of the recreational catches are illegally commercialized, affecting the fish demand of the SSF as well (Merino et al., 2008).

The main aim of fisheries management is the sustainable exploitation of living resources, which also requires the conservation of marine ecosystems (Worm et al., 2009). This is a very important issue in the Balearic Islands where, as already mentioned, the red algae beds (maërl) overlap with traditional fishing grounds of both the BTF and SSF. Consequently, a proper implementation of the EAFM in the area should make compatible the conservation of these habitats and the sustainability of fisheries. This is a great challenge owing to the strong decrease in the number of fishing vessels observed in the Balearic Islands during the last decades. In case such a decrease is maintained, it might lead the fishing sector to its final disappearance, which seems not too far away in the case of bottom trawlers (Figure 6). Another option would be to stabilize the fleet in such a low number of trawlers that it will ensure the sustainable exploitation of the resources. In this second case, however, fisheries management should also ensure that such a low number of vessels will also allow the viability and maintenance of the fish market chain, from fishers to consumers. Needless to mention the 
maintenance of local traditions, culture, and gastronomy within the current framework of a globalized world, especially in an area so highly dependent on tourism as the Balearic Islands. Therefore, urgent measures must be taken to improve both the profitability of commercial fishing and its attractiveness to young people, so as to guaranty the maintenance of sustainable fisheries and the protection of the marine environment.

Although the ecosystem-based management is complex and difficult to operationalize, whereby progresses have been somewhat limited, the steps taken so far are worthy for future progresses (Link and Browman, 2017). The lack of proper datasets is no more an excuse to avoid implementing the EAFM since it is feasible with the information, tools and approaches currently available (Patrick and Link, 2015). This study is a first step toward the implementation of the EAFM in the Balearic Islands by means of the development of a harvest strategy and it is intended to be a working example of co-management (fishers, policy-makers, and scientists) in the Mediterranean in the framework of the new EU CFP.

\section{REFERENCES}

Aanesen, M., Armstrong, C. W., Bloomfield, H. J., and Roeckmann, C. (2014). What does stakeholder involvement mean for fisheries management? Ecol. Soc. 19:35. doi: 10.5751/ES-06947-190435

Acheson, J., and Gardner, R. (2011). The evolution of the maine lobster Vnotch practice: cooperation in a prisoner's dilemma game. Ecol. Soc. 16:41. doi: 10.5751/ES-04004-160141

Ardizzone, G. D. (2006). “An introduction to Sensitive and Essential Fish Habitats identification and protection in the Mediterranean Sea," in Working Document to the STECF/SGMED-06-01 Subgroup Meeting on Sensitive and Essential Fish Habitats in the Mediterranean (Rome).

Bellido, J. M., Begona Santos, M., Grazia Pennino, M., Valeiras, X., and Pierce, G. J. (2011). Fishery discards and bycatch: solutions for an ecosystem approach to fisheries management? Hydrobiologia 670, 317-333. doi: 10.1007/s10750-011-0721-5

Bertrand, J. A., de Sola, L. G., Papaconstantinou, C., Relini, G., and Souplet, A. (2002). The general specifications of the MEDITS surveys. Sci. Mar. 66, 9-17. doi: 10.3989/scimar.2002.66s29

Caddy, J. F. (2002). Limit reference points, traffic lights, and holistic approaches to fisheries management with minimal stock assessment input. Fish. Res. 56, 133-137. doi: 10.1016/S0165-7836(01)00343-5

Caddy, J. F., Wade, E., Surette, T., Hebert, M., and Moriyasu, M. (2005). Using an empirical traffic light procedure for monitoring and forecasting in the Gulf of St. Lawrence fishery for the snow crab, Chionoecetes opilio. Fis. Res. 76, 123-145. doi: 10.1016/j.fishres.2005.06.003

Carreras, M., and Cornax, M. (2011). Propuesta de OCEANA Para una Pesca Responsable En las Illes Balears. 1-72. OCEANA. Available online at: http://oceana.org/node/20497

Carreras, M., Coll, M., Quetglas, A., Goñi, R., Pastor, X., Cornax, M. J., et al. (2015). Estimates of Total Fisheries Removal for the Balearic Islands (19502010). Fisheries Center; The University of British Columbia; Working Paper 2015-2019, 46.

Ceriola, L., Ungaro, N., and Toteda, F. (2007). A “Traffic" Light approach for the assessment of the Broadtail shortfin squid Illex coindetii Verany, 1839 in the Southern Adriatic Sea (Central Mediterranean). Rev. Fish Biol. Fish. 17, 145-157. doi: 10.1007/s11160-006-9019-5

Coll, J., Linde, M., Garcia-Rubies, A., Riera, F., and Grau, A. M. (2004). Spear fishing in the Balearic Islands (west central Mediterranean): species affected and catch evolution during the period 1975-2001. Fish. Res. 70, 97-111. doi: 10.1016/j.fishres.2004.05.004

\section{AUTHOR CONTRIBUTIONS}

All authors participated actively in the Myfish project and the development of this Regional Implementation Plan (RIP). Scientists performed all data analyses (AQ, GM, JG, FO, BG, PO, and EM). Stakeholders (AG and AMG) provided information for data analyses and expertise for interpreting results and designing the RIP. All authors contributed to the writing of the manuscript.

\section{ACKNOWLEDGMENTS}

The research leading to these results has received funding from the European Community's Seventh Framework Programme (FP7/2007-2013) under grant agreement MYFISH no. 289257. The article does not necessarily reflect the views of the Commission. Figures 1, 2, 5 and $\mathbf{6}$ were edited by Antonia and Miquel from On Accent (http://www.onaccent.com/), while Figures 3 and 4 were produced by Paul Baranowski from Imperial College London.

Coll, M., Carreras, M., Cornax, M., Massuti, E., Morote, E., Pastor, X., et al. (2014). Closer to reality: reconstructing total removals in mixed fisheries from Southern Europe. Fish. Res. 154, 179-194. doi: 10.1016/j.fishres.2014. 01.013

Colloca, F., Cardinale, M., Maynou, F., Giannoulaki, M., Scarcella, G., Jenko, K., et al. (2013). Rebuilding Mediterranean fisheries: a new paradigm for ecological sustainability. Fish Fish. 14, 89-109. doi: 10.1111/j.1467-2979.2011.00453.x

Colloca, F., Carpentieri, P., Balestri, E., and Ardizzone, G. D. (2004). A critical habitat for Mediterranean fish resources: shelf-break areas with Leptometra phalangium (Echinodermata: Crinoidea). Mar. Biol. 145, 1129-1142. doi: 10.1007/s00227-004-1405-8

Deroba, J. J., and Bence, J. R. (2008). A review of harvest policies: understanding relative performance of control rules. Fish. Res. 94, 210-223. doi: 10.1016/j.fishres.2008.01.003

Dichmont, C., Pascoe, S., Kompas, T., Punt, A., E., and Deng, R. (2010). On implementing maximum economic yield in commercial fisheries. Proc. Natl. Acad. Sci. U.S.A. 107, 16-21. doi: 10.1073/pnas.0912091107

Dowling, N. A., Smith, D. C., Knuckey, I., Smith, A. D. M., Domaschenz, P., Patterson, H. M., et al. (2008). Developing harvest strategies for low-value and data-poor fisheries: case studies from three Australian fisheries. Fish. Res. 94, 380-390. doi: 10.1016/j.fishres.2008.09.033

Eliasen, S., Q., Hegland, T. J., and Raakjaer, R. (2015). Decentralising: the implementation of regionalisation and co-management under the post-2013 Common Fisheries Policy. Mar. Policy 62, 224-232. doi: 10.1016/j.marpol.2015.09.022

European Commission (2014). Facts and Figures on the Common Fisheries Policy: Basic Statistical Data, 2014 Edn. Luxemburg: Publications Office of the European Union, 44 pp.

García, S. M., Zerbi, A., Aliaume, C., Do Chi, T., and Lasserre, G. (2003). The ecosystem approach to fisheries. Issues, terminology, principles, institutional foundations, implementation and outlook. FAO Fish. Tech. Pap. 443, 1-71.

GFCM (2014). Report of the Working Group on Stock Assessment of Demersal Species (WGSAD). Rome. Available online at: http://www.fao.org/3/a-ax810e. pdf

Goñi, R., Mallol, S., Díaz, D., Mora, J., Mateo, A., and Muñoz, A. (2013). Estudio Integral de la Langosta roja (Palinurus elephas) en Las Islas Baleares Para el Diseño de un Sistema de Gestión Pesquera Sostenible. Informe final 2013 proyecto LANBAL. Proyecto LANBAL (2010-2013), IEO-COB/LANBAL/13-1, p. 90.

Guijarro, B., and Massuti, E. (2006). Selectivity of diamond- and squaremesh codends in the deepwater crustacean trawl fishery off the 
Balearic Islands (western Mediterranean). ICES J. Mar. Sci. 63, 52-67. doi: 10.1016/j.icesjms.2005.08.011

Guijarro, B., Tserpes, G., Moranta, J., and Massuti, E. (2011). Assessment of the deep water trawl fishery off the Balearic Islands (western Mediterranean): from single to multi-species approach. Hydrobiologia 670, 67-85. doi: 10.1007/s10750-011-0670-Z

Guijarro, B., Quetglas, A., and Morillas, A. (2012a). La Importància del Sector Pesquer en la Investigació Oceanogràfica. Centre Oceanogràfic de les Balears \& Direcció General d' Universitats; Recerca i Transferència del Coneixement; Palma de Mallorca, 52.

Guijarro, B., Quetglas, A., Moranta, J., Ordines, F., Valls, M., Gonzalez, N., et al. (2012b). Inter- and intra-annual trends and status indicators of nektobenthic elasmobranchs off the Balearic Islands (northwestern Mediterranean). Sci. Mar. 76, 87-96. doi: 10.3989/scimar.03432.22A

Guillen, J., Macher, C., Merzereaud, M., Bertignac, M., Fifas, S., and Guyader, O. (2013). Estimating MSY and MEY in multi-species and multi-fleet fisheries, consequences and limits: an application to the Bay of Biscay mixed fishery. Mar. Policy 40, 64-74. doi: 10.1016/j.marpol.2012.12.029

Guyader, O., Berthou, P., Koutsikopoulos, C., Alban, F., Demaneche, S., Gaspar, M., et al. (2013). Small scale fisheries in Europe: a comparative analysis based on a selection of case studies. Fish. Res. 140,1-13. doi: 10.1016/j.fishres.2012.11.008

Halliday, R. G., Fanning, L. P., and Mohn, R. K. (2001). Use of the Traffic Light Method in Fishery Management Planning. Canadian Science Advisory Secretariat Research Document 2001/108.

Jennings, S., and Rice, J. (2011). Towards an ecosystem approach to fisheries in Europe: a perspective on existing progress and future directions. Fish Fish. 12, 125-137. doi: 10.1111/j.1467-2979.2011.00409.x

Koeller, P., Savard, L., Parsons, D. G., and Fu, C. (2000). A precautionary approach to assessment and management of red shrimp stocks in the Nortwest Atlantic. J. Northw. Atlant. Fish. Sci. 27, 235-246. doi: 10.2960/J.v27.a20

Kvamsdal, S. F., Eide, A., Ekerhovd, N. A., Enberg, K., Gudmundsdottir, A., Hoel, A. H., et al. (2016). Harvest control rules in modern fisheries management. Elementa 4:000114. doi: 10.12952/journal.elementa.000114

Link, J. S. (2013). Ecosystem approaches to fisheries: a global perspective. Fisheries 38:463. doi: 10.1080/03632415.2013.851556

Link, J. S., and Browman, H. I. (2017). Operationalizing and implementing ecosystem-based management. ICES J. Mar. Sci. 74, 379-381. doi: 10.1093/icesjms/fsw247

Lleonart, J., and Maynou, F. (2003). Fish stock assessments in the Mediterranean: state of the art. Sci. Mar. 67, 37-49. doi: 10.3989/scimar.2003.67s137

Lleonart, J., Maynou, F., Recasens, L., and Franquesa, R. (2003). A bioeconomic model for Mediterranean fisheries, the hake off Catalonia (western Mediterranean) as a case study. Sci. Mar. 67, 337-351. doi: 10.3989/scimar.2003.67s1337

Mackinson, S., Deas, B., Beveridge, D., and Casey, J. (2009). Mixed-fishery or ecosystem conundrum? Multispecies considerations inform thinking on longterm management of North Sea demersal stocks. Can. J. Fish. Aquat. Sci. 66, 1107-1129. doi: 10.1139/F09-057

Marzloff, M. P., Melbourne-Thomas, J., Hamon, K. G., Hoshino, E., Jennings, S., van Putten, I. E., et al. (2016). Modelling marine community responses to climate-driven species redistribution to guide monitoring and adaptive ecosystem-based management. Glob. Chang. Biol. 22, 2462-2474. doi: $10.1111 /$ gcb.13285

Massutí, E., and Guijarro, B. (2004). Recursos Demersales en Los Fondos de Arrastre de La Plataforma y el Talud de Mallorca y Menorca (Illes Balears). Resultados de las campañas BALAR0401 y BALAR0901. Informes Técnicos del Instituto Español de Oceanografía.

Maunder, M. N. (2008). Maximum sustainable yield. Encycloped. Ecol. 5, 2292-2296. doi: 10.1016/b978-008045405-4.00522-x

Merino, G., Morales-Nin, B., Maynou, F., and Grau, A. M. (2008). Assessment and bioeconomic analysis of the Majorca (NW Mediterranean) trammel net fishery. Aquat. Living Resour. 21, 99-107. doi: 10.1051/alr:2008027

Merino, G., Quetglas, A., Maynou, F., Garau, A., Arrizabalaga, H., Murua, H., et al. (2015). Improving the performance of a Mediterranean demersal fishery toward economic objectives beyond MSY. Fish. Res. 161, 131-144. doi: 10.1016/j.fishres.2014.06.010

Morales-Nin, B., Moranta, J., Garcia, C., Tugores, M. P., Grau, A. M., Riera, F., et al. (2005). The recreational fishery off Majorca Island (western Mediterranean): some implications for coastal resource management. ICES J. Mar. Sci. 62, 727-739. doi: 10.1016/j.icesjms.2005.01.022

Morales-Nin, B., Moranta, J., Garcia, C., Tugores, P., and Grau, A. M. (2008). "Evaluation of the importance of recreational fisheries on a Mediterranean island," in Reconciling Fisheries with Conservation: Proceedings of the Fourth World Fisheries Congress, eds J. Nielsen, J. J. Dodson, K. Friedland, T. R. Hamon, J. Musick, and E. Verspoor (Portland: American Fisheries Society Symposium), 445-450.

Morales-Nin, B., Cardona-Pons, F., Maynou, F., and Maria Grau, A. (2015). How relevant are recreational fisheries? Motivation and activity of resident and tourist anglers in Majorca. Fish. Res. 164, 45-49. doi: 10.1016/j.fishres.2014.10.010

Mueter, F. J., and Megrey, B. A. (2006). Using multi-species surplus production models to estimate ecosystem-level maximum sustainable yields. Fish. Res. 81, 189-201. doi: 10.1016/j.fishres.2006.07.010

Ogier, E. M., Davidson, J., Fidelman, P., Haward, M., Hobday, A. J., Holbrook, N. J., et al. (2016). Fisheries management approaches as platforms for climate change adaptation: comparing theory and practice in Australian fisheries. Mar. Policy 71, 82-93. doi: 10.1016/j.marpol.2016.05.014

Ordines, F. (2015). Habitats and Nekto-Benthic Communities of the BottomTrawl Fishery Developed on the Continental Shelf of the Balearic Islands. PhD Universitat de les Illes Balears, Palma de Mallorca, 228.

Ordines, F., and Massuti, E. (2009). Relationships between macro-epibenthic communities and fish on the shelf grounds of the western Mediterranean. Aquat. Conserv. Mar. Freshw. Ecosyst. 19, 370-383. doi: 10.1002/ aqc.969

Ordines, F., Massuti, E., Guijarro, B., and Mas, R. (2006). Diamond vs. square mesh codend in a multi-species trawl fishery of the western Mediterranean: effects on catch composition, yield, size selectivity and discards. Aquat. Living Resour. 19, 329-338. doi: 10.1051/alr:2007003

Ordines, F., Quetglas, A., Massuti, E., and Moranta, J. (2009). Habitat preferences and life history of the red scorpion fish, Scorpaena notata, in the Mediterranean. Estuar. Coast. Shelf Sci. 85, 537-546. doi: 10.1016/j.ecss.2009. 09.020

Ordines, F., Jorda, G., Quetglas, A., Flexas, M., Moranta, J., and Massuti, E. (2011). Connections between hydrodynamics, benthic landscape and associated fauna in the Balearic Islands, western Mediterranean. Cont. Shelf Res. 31, 1835-1844. doi: 10.1016/j.csr.2011.08.007

Ordines, F., Farriols, M., Lleonart, J., Guijarro, B., Quetglas, A., and Massuti, E. (2014). Biology and population dynamics of by-catch fish species of the bottom trawl fishery in the western Mediterranean. Mediterr. Mar. Sci. 15, 613-625. doi: $10.12681 / \mathrm{mms} .812$

Ordines, F., Bauza, M., Sbert, M., Roca, P., Gianotti, M., and Massuti, E. (2015). Red algal beds increase the condition of nekto-benthic fish. J. Sea Res. 95, 115-123. doi: 10.1016/j.seares.2014.08.002

Palmer, M., Quetglas, A., Guijarro, B., Moranta, J., Ordines, F., and Massuti, E. (2009). Performance of artificial neural networks and discriminant analysis in predicting fishing tactics from multispecific fisheries. Can. J. Fish. Aquat. Sci. 66, 224-237. doi: 10.1139/F08-208

Patrick, W. S., and Link, J. S. (2015). Myths that continue to impede progress in Ecosystem-Based Fisheries Management. Fisheries 40, 155-160. doi: 10.1080/03632415.2015.1024308

Pauly, D., Ulman, A., Piroddi, C., Bultel, E., and Coll, M. (2014). 'Reported' versus 'likely' fisheries catches of four Mediterranean countries. Sci. Mar. 78, 11-17. doi: 10.3989/scimar.04020.17A

Pelletier, D., and Ferraris, J. (2000). A multivariate approach for defining fishing tactics from commercial catch and effort data. Can. J. Fish. Aquat. Sci. 57, 51-65. doi: 10.1139/f99-176

Pikitch, E. K., Santora, C., Babcock, E. A., Bakun, A., Bonfil, R., Conover, D. O., et al. (2004). Ecosystem-based fishery management. Science 305, 346-347. doi: $10.1126 /$ science. 1098222

Prager, M. H. (2004). User's Manual for ASPIC: A Stock-Production Model Incorporating Covariates (ver. 5) and Auxiliary Programs. National Marine Fisheries Service; Beaufort Laboratory Document BL-2004-01, 1-27.

Punt, A. E. (2010). "Harvest control rules and fisheries management," in Handbook of Marine Fisheries Conservation and Management, eds R. Q. Grafton, R. Hilborn, D. Squires, M. Tait, and M. Williams (New York, NY: Oxford University Press, Inc.), 582-594. 
Punt, A. E., Smith, D. C., Tuck, G. N., and Methot, R. D. (2006). Including discard data in fisheries stock assessments: two case studies from south-eastern Australia. Fish. Res. 79, 239-250. doi: 10.1016/j.fishres.2006. 04.007

Quetglas, A., Guijarro, B., Ordines, F., and Massuti, E. (2012). Stock boundaries for fisheries assessment and management in the Mediterranean: the Balearic Islands as a case study. Sci. Mar. 76, 17-28. doi: 10.3989/scimar.2012. $76 \mathrm{n} 1017$

Quetglas, A., Ordines, F., Hidalgo, M., Monserrat, S., Ruiz, S., Amores, A., et al. (2013). Synchronous combined effects of fishing and climate within a demersal community. ICES J. Mar. Sci. 70, 319-328. doi: 10.1093/icesjms/ fss 181

Quetglas, A., Keller, S., and Massutí, E. (2015). Can Mediterranean cephalopod stocks be managed at MSY by 2020? The Balearic Islands as a case study. Fish. Manage. Ecol. 22, 349-358. doi: 10.1111/fme.12131

Quetglas, A., Rueda, L., Alvarez-Berastegui, D., Guijarro, B., and Massutí, E. (2016). Contrasting responses to harvesting and environmental drivers of fast and slow life history species. PLoS ONE 11:e0148770. doi: 10.1371/journal.pone.0148770

Ramirez-Monsalve, P., Raakjaer, J., Nielsen, K. N., Santiago, J. L., Ballesteros, M., Laksa, U., et al. (2016). Ecosystem Approach to Fisheries Management (EAFM) in the EU-Current science-policy-society interfaces and emerging requirements. Mar. Policy 66, 83-92. doi: 10.1016/j.marpol.2015. 12.030

Ratz, H. J., Bethke, E., Dorner, H., Beare, D., and Groger, J. (2007). Sustainable management of mixed demersal fisheries in the North Sea through fleet-based management: a proposal from a biological perspective. ICES J. Mar. Sci. 64, 652-660. doi: 10.1093/icesjms/fsm030

Röckmann, C., van Leeuwen, J., Goldsborough, D., Kraan, M., and Piet, G. (2015). The interaction triangle as a tool for understanding stakeholder interactions in marine ecosystem based management. Mar. Policy 52, 155-162. doi: 10.1016/j.marpol.2014.10.019

Samy-Kamal, M., Forcada, A., and Sanchez Lizaso, J. L. (2015). Daily variation of fishing effort and ex-vessel prices in a western Mediterranean multi-species fishery: implications for sustainable management. Mar. Policy 61, 187-195. doi: 10.1016/j.marpol.2015.08.015
Smith, A. D., and Garcia, S. A. (2014). Fishery management: contrasts in the Mediterranean and the Atlantic. Curr. Biol. 24, R810-R812. doi: $10.1016 /$ j.cub.2014.07.031

STECF (2012). Assessment of Mediterranean Sea Stocks, Part 1 (STECF 12-19). Available online at: https://stecf.jrc.ec.europa.eu/c/document_library/get_file? uuid=3ffele0f-f579-40d5-a5b8-43537fb7a4e0 \&groupId $=43805$

STECF (2013). Assessment of Mediterranean Sea Stocks Part 2 (STECF 14-08). Available online at: https://stecf.jrc.ec.europa.eu/documents/43805/664390/ 2014-04_STECF+14-08+2013+Med+assessments+part+2_JRC89860.pdf

STECF (2014). Assessment of Mediterranean Sea Stocks, Part 2 (STECF-15-06). Available online at: https://stecf.jrc.ec.europa.eu/c/document_library/get_file? uuid $=8 \mathrm{bdb} 8675-76 \mathrm{ee}-4 \mathrm{db} 8-91 \mathrm{f3}-\mathrm{cld} 8805 \mathrm{a} 0 \mathrm{fe} 0$ \&groupId $=43805$

Telsnig, J. D. (2013). An Assessment of the Impact of V-Notching European Lobsters in the Northumberland District. MST8023 Marine Consultancy 2013-1024; Newcastle University, 28.

van Hoof, L. (2015). Fisheries management, the ecosystem approach, regionalisation and the elephants in the room. Mar. Policy 60, 20-26. doi: 10.1016/j.marpol.2015.05.011

Vasilakopoulos, P., Maravelias, C. D., and Tserpes, G. (2014). The alarming decline of Mediterranean fish stocks. Curr. Biol. 24, 1643-1648. doi: 10.1016/j.cub.2014.05.070

Worm, B., Hilborn, R., Baum, J. K., Branch, T. A., Collie, J. S., Costello, C., et al. (2009). Rebuilding global fisheries. Science 325, 578-585. doi: $10.1126 /$ science. 1173146

Conflict of Interest Statement: The authors declare that the research was conducted in the absence of any commercial or financial relationships that could be construed as a potential conflict of interest.

Copyright (c) 2017 Quetglas, Merino, González, Ordines, Garau, Grau, Guijarro, Oliver and Massutí. This is an open-access article distributed under the terms of the Creative Commons Attribution License (CC BY). The use, distribution or reproduction in other forums is permitted, provided the original author (s) or licensor are credited and that the original publication in this journal is cited, in accordance with accepted academic practice. No use, distribution or reproduction is permitted which does not comply with these terms. 